\title{
PEMBINAAN PENGURUS PERSAUDARAAN BELADIRI KEMPO INDONESIA (PERKEMI) DOJO SORAWOLIO DALAM MELAKSANAKAN PERAN DAN FUNGSI MANAJEMEN ORGANISASI
}

\author{
Hardin \\ Fakultas Pertanian Universitas Muhammadiyah Buton \\ e-mail: hardinspmm@gmail.com
}

\begin{abstract}
ABSTRAK
Tujuan dari program Pengabdian Kepada Masyarakat adalah untuk mengetahui proses pembinaan pengurus Persaudaraan Beladiri Kempo Indonesia (PERKEMI) Dojo Sorawolio Dalam Melaksanakan Peran dan Fungsi Organisasi, agar pengetahuan dan keterampilan baik pimpinan maupun anggota dapat meningkat. Kesimpulan dari Pengabdian Kepada Masyarakat adalah proses pembinaan pengurus Persaudaraan Beladiri Kempo Indonesia (PERKEMI) Dojo Sorawolio Dalam Melaksanakan Peran dan Fungsi Organisasi, dengan metode teori dan praktek tentang manajemen perkantoran modern, teknik mengarsip surat dasar, penyelenggaraan rapat, tata cara pembuatan laporan dan pengenalan teknologi informasi Setelah diberikan teori menyangkut 5 pokok bahasan tersebut, berdasarkan nilai pretest tentunya dijadikan sebagai rujukan awal, dimana nilai pretest yang paling rendah adalah 34 dan nilai pretest yang tertinggi adalah 64 dan rata-rata nilai pretest adalah 52,8 dari 20 peserta yang mengikuti pretest. Sedangkan nilai posttest paling rendah adalah 78 dan posttest paling tinggi adalah 95 dengan rata-rata 87,65 berarti terjadi peningkatan atau perbaikan pengetahuan dan keterampilan sebelum kegiatan dilaksanakan dan setelah kegiatan dilaksanakan
\end{abstract}

Kata Kunci: Pembinaan Pengurus PERKEMI, Peran, Fungsi Organisasi

\section{A. PENDAHULUAN}

Persaudaraan Beladiri Kempo Indonesia atau yang di singkat dengan PERKEMI untuk Pengurus Cabang Kota Baubau telah berdiri semenjak tahun 1995 sampai sekarang dan telah memiliki Dojo atau tempat latihan sebanyak 4 (empat) yaitu Dojo Sorawolio bertempat di Kantor Camat Sorawolio, Dojo SMA 2 bertempat di SMA Negeri 2 Baubau, Dojo SMA 4 Baubau bertempat di SMA Negeri 4 Baubau dan Dojo SMA 3 Baubau bertempat di SMA Negeri 3 Baubau. Proses Pembinaan Pengurus yang menjadi perhatian dalam Pengabdian Kepada Masyarakat adalah dojo tertua di Kota Baubau yaitu Dojo Sorawolio, dimana 
Ketua Dojo tersebut saat ini di pimpin oleh Bapak Arianto, S.P. dan Sekertaris Faais Mufaasir Ramadhan.

Tanggung jawab yang dilaksanakan dojo ini sangat banyak yaitu disamping menjalankan latihan sesuai jadwal juga menjalankan administrasi agar kesinambungan organisasi dapat berjalan dengan baik, dan rata-rata yang bergabung dalam Dojo Sorawolio, yairu semua kalangan baik usia anak-anak, usia remaja atau pemuda dan usia orang tua, yang tujuannya diharapkan untuk memajukan olahraga Kempo di Kota Baubau. Melalui pengkaderan di Dojo Sorawolio ini sudah banyak melahirkan atlit-atlit yang potensial dan berprestasi baik di tingkat lokal, regional maupun nasional dibuktikan dengan berbagai medali baik emas, perak maupun perunggu yang telah diperoleh, Namun dibalik kesuksesan tersebut, juga banyak permasalahan yang muncul, misalnya dalam latihan yang tidak memiliki alat standar, selama latihan tidak memiliki standar operasional prosedur (SOP) yang memisahkan antara yang kondisinya normal dengan yang tidak normal, tidak memiliki program latihan yang jelas kapan latihan pemanasan, kapan latihan fisik, kapan latihan kelincahan dan bagaimana program-program yang dilaksanakan untuk menghadapi pertandingan yang membutuhkan kesiapan yang matang agar tidak ada atlit yang cepat lelah apalagi cedera, seperti yang dialami oleh salah satu atlit putri yang cedera pada saat bertanding, serta tata persuratan yang menurut penilaian kami masih harus dibenahi agar dojo ini disamping menjadi dojo yang tertua juga diharapkan semakin professional peran dan fungsi manajemen organisasi, mulai dari pimpinan pengurus dojo sampai pada anggotanya hendaknya dapat menjalankan roda organisasi sesuai dengan prosedur normatif yang telah digariskan oleh organisasi, sehingga akan bersinergi antara program pusat, daerah provinsi dan daerah kabupaten/kota maupun dojo.

Manajemen pada dasarnya adalah upaya untuk mengatur segala sesuatu (sumber daya) untuk mencapai tujuan organisasi. Pendapat berikut merupakan sebuah grand theory dari Terry (2008: 48) yang menyatakan bahwa manajemen adalah payung dari sumber daya manusia yang mengatur potensi sumber daya manusia dalam suatu organisasi untuk mencapai tujuan organisasi. Dari uraian tersebut, maka terdapat 3 (tiga) komponen dalam manajemen yaitu manusia, 
organisasi dan tujuan. Manusia adalah yang menggerakkan, mengatur, menjalankan kegiatan organisasi dan memikul tanggung jawab dalam setiap kegiatan manajemen, organisasi adalah wadah tempat menyalurkan segala potensi sumber daya manusia yang tergabung dalam organisasi, serta tujuan merupakan harapan bersama atau cita-cita untuk mewujudkan kesejahteraan bersama.

Manajemen sebagai ilmu dan seni. Manajemen sebagai ilmu adalah suatu kumpulan pengetahuan yang logis dan sistematis. Manajemen sebagai seni adalah suatu kreaktivitas pribadi yang disertai suatu keterampilan dalam mengembangkan manajemen sebagai inti dari seni berilmu (Terry, 2008: 69). Tahapan pengembangan manajemen, salah satu cabang dari ilmu manajemen adalah sumber daya manusia yang menjadi middle theory dalam memahami pentingnya manajemen sumber daya manusia sebagai ilmu pengetahuan sekaligus seni yang menjadikan manusia sebagai bagian terpenting dari organisasi.

Manajemen sumber daya manusia (MSDM) merupakan bagian integral dari manajemen keorganisasian yang memusatkan perhatiannya pada unsur manusia. Unsur manusia (man) ini berkembang menjadi suatu bidang ilmu khusus untuk mempelajari bagaimana mengatur proses pemanfaatan sumber daya manusia secara efektif dan efisien untuk mencapai tujuan tertentu dan dapat memberikan kepuasan bagi semua pihak (Ardana, dkk. 2012: 3).

Manajemen sumber daya manusia dilihat dari susunan katanya terdiri dari dua kelompok kata yakni manajemen dan sumber daya manusia. Manajemen berasal dari kata to manage yang berarti mengelola, menata, mengurus, mengatur, melaksanakan dan mengendalikan. Manajemen adalah ilmu dan seni mengatur proses pemanfaatan sumber daya manusia dan sumber daya lainnya secara efektif dan efisien untuk mencapai tujuan tertentu. Manajemen sebagai ilmu dimaksudkan bahwa manajemen dapat dipelajari dan menjadi salah satu cabang ilmu pengetahuan, dapat diterapkan untuk memecahkan persoalan-persoalan dalam perusahaan serta untuk mengambil kepuasan oleh pimpinan/manajer, sedangkan manajemen sebagai suatu seni ialah bahwa dalam mencapai tujuan 
yang diinginkan, seorang pimpinan sangat tergantung pada kemampuannya untuk mempengaruhi orang lain yang ada di bawahnya (Ardana, dkk., 2012: 4).

Manajemen sumber daya manusia merupakan salah atu bidang dari manajemen umum yang meliputi segi-segi perencanaan, pengorganisasian, pelaksanaan dan pengendalian. Karena sumber daya manusia dianggap semakin penting perannya dalam pencapaian tujuan perusahaan, maka berbagai pengalaman dan hal penelitian dalam bidang sumber daya manusia dikumpulkan secara sistematis dalam apa yang di sebut manajemen sumber daya manusia. Istilah "manajemen" mempunyai arti sebagai kumpulan pengetahuan tentang bagaimana seharusnya memanage (mengelola) sumber daya manusia (Rivai dan Jauvani Sagala 2009: 1).

Ardana, dkk. (2012: 5) mengemukakan bahwa sumber daya manusia merupakan kemampuan untuk berbuat sesuatu, dan memanfaatkan kesempatan yang ada, dan kemampuan untuk bisa membebaskan diri dari kesulitan yang dialami. Manusia dengan dibekali daya cipta, rasa dan karsa akan memiliki kemampuan untuk membebaskan diri dari kesulitan dan berusaha mencari keuntungan pada setiap peluang yang ada di sekitarnya. Manusia dengan budaya yang dimiliki dapat menentukan tinggi rendahnya nilai terhadap suatu sumber daya, sehingga perlu meningkatkan sumber daya manusia itu sendiri.

Moekijat (2010: 4) mendefinisikan bahwa manajemen sumber daya manusia sebagai proses pencapaian tujuan organisasi melalui mendapatkan, mempertahankan, memberhentikan, mengembangkan, dan menggunakan /memanfaatkan sumber daya manusia dalam suatu organisasi dengan sebaikbaiknya. Jadi manajemen sumber daya manusia merupakan bagian dari manajemen keorganisasian yang memfokuskan diri pada unsur sumber daya manusia. Manajemen sumber daya manusia mempunyai tugas untuk mengelola unsur manusia secara baik agar diperoleh tenaga kerja yang puas akan pekerjaaannya.

Marwansyah (2010: 3) berpendapat bahwa manajemen sumber daya manusia diartikan sebagai pendayagunaan sumber daya manusia di dalam organisasi yang dilakukan melalui fungsi-fungsi perencanaan sumber daya manusia, rekruitmen dan seleksi, pengembangan sumber daya manusia, 
perencanaan dan pengembangan karir, pemberian kompensasi dan kesejahteraan, keselamatan dan kesehatan kerja, dan hubungan industrial. Perencanaan dan implementasi fungsi-fungsi ini harus di dukung oleh analisis jabatan yang cermat dan penilaian kinerja yang obyektif.

Manajemen sumber daya manusia merupakan suatu bidang manajemen yang mempelajari hubungan dan peranan manusia dalam organisasi atau perusahaan. Fokus yang dipelajari dalam MSDM adalah masalah yang terkait dengan tenaga kerja manusia. MSDM adalah suatu pendekatan dalam mengelola masalah-masalah yang berdasarkan 3 (tiga) prinsip dasar yaitu:

1. Sumber daya manusia adalah harta atau asset yang paling berharga dan paling penting dimiliki oleh satu organisasi/perusahaan, karena keberhasilan organisasi sangat ditentukan oleh unsur manusia. Manusia berperan sebagai perencana, pelaksana dan sekaligus pengendali terwujudnya tujuan organisasi/perusahaan. Di samping itu tidak ada satu pun organisasi tanpa manusia didalamnya yang dapat menggerakkan organisasi/perusaaan itu.

2. Keberhasilan itu sangat mungkin di dapat jika kebijakan dari perusahaan dan peraturan yang berkaitan dengan manusia dari perusahaan saling berhubungan dan menguntungkan semua pihak yang terlibat di dalam perusahaan. Pihak yang terlibat secara tidak langsung adalah semua faktor eksternal seperti: pemasok, investor, pelanggan, pemerintah dan masyarakat.

3. Budaya dan nilai perusahaan serta prilaku manajerial yang berasal dari budaya tersebut akan memberikan pengaruh besar terhadap pencapaian hasil terbaik. Oleh karena itu, budaya perusahaan dari etos kerja harus ditegakkan secara terus menerus mulai dari pucuk pimpinan sampai penyelia agar budaya tersebut dapat diterima dan di patuhi (Ardana, 2012: 6).

Pengertian yang sama dikemukakan oleh Kaswan (2012: 5) bahwa manajemen sumber daya manusia adalah asset yang paling penting yang berkaitan dengan manusia dari suatu organisasi, sedangkan manajemen yang efektif adalah kunci penting bagi keberhasilan organisasi.

Berdasarkan kenyataan tersebut, maka perlu adanya pembinaan pengurus PERKEMI Dojo Sorawolio, dengan memberikan pengetahuan tentang manajemen 
terutama yang menyangkut peran dan fungsi pimpinan dan seluruh pengurus yang terlibat dalam Dojo Sorawolio, dengan metode yaitu mengaplikasikan keterampilan tentang penguatan administrasi pada berbagai kegiatan dojo baik secara internal maupun eksternal, agar tujuan olah raga bena-benar akan menyehatkan semua bukan menimbulkan masalah baru berupa penyakit, apalagi menimbulkan penyakit seumur hidup.

Adapun rumusan masalah dari program Pengabdian Kepada Masyarakat adalah bagaimana proses pembinaan pengurus Persaudaraan Beladiri Kempo Indonesia (PERKEMI) Dojo Sorawolio Dalam Melaksanakan Peran dan Fungsi Organisasi, agar pengetahuan dan keterampilan baik pimpinan maupun anggota dapat meningkat?

\section{B. METODE}

Metode yang digunakan dalam kegiatan Pengabdian Kepada Masyarakat (PPM) adalah melalui pelatihan manajemen organisasi dengan sistem ceramah, diskusi dengan mengidentifikasi kasus per kasus, pemecahan kasus dan melakukan demonstrasi (Hardin dan Indah Kusuma Dewi (2018: 37), serta simulasi. Peserta terdiri dari seluruh pengurus mulai dari Ketua Umum sampai pada anggota dimana jumlah seluruhnya adalah 20 orang.

\section{HASIL DAN PEMBAHASAN}

Pelatihan ini berlansung selama 5 hari, dari tanggal 10-15 Desember 2018, dilaksanakan di Sekretariat Kempo Dojo Sorawolio dengan alamat Jalan Poros Baubau Pasar Wajo Km 14. Pelatihan ini berlangsung dari jam 08.00-14.00 WITA. Kegiatan ini diiukuti oleh 20 orang peserta dan para peserta mengikuti kegiatan ini dengan penuh antusias mulai dari awal hingga akhir kegiatan dengan menggunakan buku Pedoman.

\section{Hasil Program/Kegiatan}

Kegiatan pelatihan ini dibuka oleh Ketua Umumnya yaitu saudara Arianto, S.P. Sebelum kegiatan dilaksanakan maka semua peserta melalui tahapan pretest untuk mendapatkan gambaran awal tentang pengetahuan mereka mengenai peran dan fungsi manajemen organisasi. Tahapan berikutnya adalah memberikan berbagai materi dengan diawali oleh permainan atau games dengan metode ceramah, diskusi dan simulasi. Adapun materinya yaitu menyangkut: 
a. Manajemen Perkantoran Modern, menyangkut Prinsip-prinsip Perkantoran Modern yaitu: Kegiatan Kesekretariatan, Ciri-ciri Perkantoran Modern, Pengelolaan Data dan Informasi, Perlindungan Terhadap Aset, Teknik-teknik Korespondensi, Fungsi Surat dan Syarat-syarat Surat yang Baik, Syarat-syarat Penulisan Surat, Bagian-bagian Surat, sambil dilakukan simulasi cara membuat surat yang baik.

b. Teknik Menarsip Surat: Dasar Arsip, Pentingnya Arsip (Filing), tujuan Arsip dan Sasaran Arsip, Siklus Hidup Arsip, Sistem Filing atau Penyimpanan Arsip, Peralatan Arsip, Menyimpan dan Menemukan Arsip, Penyusunan Arsip, Karakteristik Arsip.

c. Penyelenggaraan Rapat: Hal-hal yang Perlu Dipersiapkan Pada Rapat-rapat Resmi, Resolusi.

d. Tata Cara pembuatan Laporan: Pengertian Pembuatan Laporan, Tujuan Laporan, Peranan Laporan, Syarat-syarat Laporan, Langkah-langkah Dalam Pembuatan Laporan, Sistematika Laporan, Menulis Laporan, dan Lampiran.

e. Teknologi Informasi: Pentingnya Teknologi Informasi (TI) Bagi Pimpinan, Tiga Komponen Utama Komputer,. TI di Kantor Modern. Fasilitas Kesekretariatan

Setelah diberikan teori menyangkut 5 pokok bahasan tersebut, maka selanjutnya di hari terakhir diadakan postes untuk mengetahui seberapa besar materi yang diberikan dapat diadopsi oleh peserta pelatihan. Nilai pretest tentunya dijadikan sebagai rujukan awal, dimana nilai Pretest yang paling rendah adalah 34 dan nilai Pretest yang tertinggi adalah 64 dan rata-rata nilai pretest adalah 52,8 dari 20 peserta yang mengikuti pretest. Sedangkan nilai posttest paling rendah adalah 78 dan posttest paling tinggi adalah 95 dengan rata-rata 87,65.

\section{Pembahasan}

Berdasarkan hasil kegiatan pelatihan proses pembinaan pengurus Persaudaraan Beladiri Kempo Indonesia (PERKEMI) Dojo Sorawolio Dalam Melaksanakan Peran dan Fungsi Organisasi, agar pengetahuan dan keterampilan baik pimpinan maupun anggota dapat meningkat dalam hal pengelolaan administrasi organisasi agar dapat berjalan sesuai dengan tujuan organisasi dalam 


\section{Jurnal Pengabdian Kepada Masyarakat \\ MEMBANGUN NEGERI \\ Vol. 3 No. 1 April 2019}

mendukung setiap kegiatan organisasi tentunya sangat diharapkan oleh para pengurus, karena dirasakan masih sangat lemah, contohnya adalah pada saat mengkonsep surat, tentunya masih banyak yang merasa masih kurang pandai, sehingga kalau ada kegiatan biasanya agak lambat dalam mengkonsep surat dapat memakan waktu 7-10 hari, tetapi dengan adanya pelatihan seperti ini rupanya dapat diselesaikan hanya sehari. Begitu juga dengan pembuatan laporan setiap kegiatan, atau laporan keuangan, tentu sangat lama dan bahkan sempat menyuruh orang lain dan di bayar, tetapi dengan adanya pelatihan ini, mereka sudah dapat membuat laporan sendiri dalam waktu 2 hari,

Hasil kegiatan tersebut secara kuantitatif adanya perkembangan dalam hal peningkatan pengetahuan setelah materi diajarkan, dan interaksi antara pembawa materi dan peserta sangat baik, hal ini setelah diadakan diskusi dan simulasi, ternyata setelah diberi waktu yang ada segala permasalah dapat tuntas selama pelatihan, apalagi dalam penguasaan teknologi informasi seperti computer dan internet, yang tadinya banyak anggota yang tidak tahu mengetik baik di words maupun excel, ternyata dengan adanya kegiatan ini, karena para peserta dianjurkan membawa laptop, akhirnya semua dapat mengetik, walaupun ada yang sudah lancar, tetapi masih banyak yang belum lancar, sehingga dalam pelatihan ini menggunakan sistem tutorial, jadi peserta yang sudah lancar dijadikan satu tim dengan yang belum lancar mengetik, tetapi dengan tidak melupakan tugastugasnya.

Menurut penilaian kami, bahwa keberhasil program ini, karena peran aktif dari peserta pelatihan yang selalu berinteraksi terutama pada pertanyaanpertanyaan lisan yang saling timbal balik antara peserta dengan pemateri, karena rasa ingin tahu yang begitu dalam, apalagi ada permainan atau games, sehingga para peserta tidak merasa jenuh bahkan termotivasi atau lebih bersemangat lagi mengikuti kegiatan ini. Keterampilan peserta ketika melaksanakan praktek dalam menjalankan peran dan fungsi manajemen pada saat simulasi, menunjukkan adanya perbaikan, hal ini dapat dilihat dari demonstrasi yang di buat, ternyata semua peserta dapat memperagakan dengan baik di banding di awal pelatihan misalnya dalam hal pengarsipan surat, pembuatan naskah surat, pembuatan laporan dan lain-lain, semuanya menunjukkan perbaikan yang sangat baik. Jika 
kita melakukan evaluasi terhadap nilai kuantitatif, dengan menjawab soal isian sederhana pada saat pretest dan soalnya beserta jawabannya dikumpulkan kembali dan sesudah itu pada saat pelaksanaa posttest. Proses yang dilakukan menunjukkan adanya peningkatan pengetahuan dan skill atau keterampilan. Jika dilihat dari nilai rata-rata, maka terjadi peningkatan dari 52,8\% menjadi 87,65.\%.

\section{SIMPULAN DAN SARAN}

\section{Simpulan}

Proses pembinaan pengurus Persaudaraan Beladiri Kempo Indonesia (PERKEMI) Dojo Sorawolio Dalam Melaksanakan Peran dan Fungsi Organisasi, dengan metode teori dan praktek tentang manajemen perkantoran modern, teknik mengarsip surat dasar, penyelenggaraan rapat, tata cara pembuatan laporan dan pengenalan teknologi informasi Setelah diberikan teori menyangkut 5 pokok bahasan tersebut, berdasarkan nilai pretest tentunya dijadikan sebagai rujukan awal, dimana nilai pretest yang paling rendah adalah 34 dan nilai pretest yang tertinggi adalah 64 dan rata-rata nilai pretest adalah 52,8 dari 20 peserta yang mengikuti pretest. Sedangkan nilai posttest paling rendah adalah 78 dan posttest paling tinggi adalah 95 dengan rata-rata 87,65 berarti terjadi peningkatan atau perbaikan pengetahuan dan keterampilan sebelum kegiatan dilaksanakan dan setelah kegiatan dilaksanakan

\section{Saran}

Agar kegiatan ini dapat berjalan dengan baik, maka perlu setiap peserta 1 (satu) laptop tidak boleh 4 (peserta) 1 (satu) laptop dan colokannnya disesuaikan dengan jumlah peserta, sehingga semua dapat praktek sesuai dengan waktu yang telah ditentukan, dan kesekretariatan harus didukung dengan sistem surat menyurat yang modern agar dapat dievaluasi berbagai kegiatan yang telah dilaksanakan contohnya mengikuti kegiatan pertandingan harus dibuatkan laporan keuangannya dan laporan kegiatannya dengan format yang telah diajarkan sehingga dapat diketahui apa yang telah diperoleh dan apakah sesuai dengan target organisasi, apa kelemahannya dan bagaimana meningkatkannya dikemudian hari.semua dapat tergambarkan dengan jelas. 


\section{DAFTAR PUSTAKA}

Ardana, I Komang, Ni Wayan Mujiati, I Wayan Mudiartha Utama. 2012. Manajemen Sumber Daya Manusia. edisi pertama. Yogyakarta: Graha Ilmu.

Hardin dan Indah Kusuma Dewi. 2018. Pengorganisasian Petani Untuk Menanam Bawang Merah di Kelurahan Kaisabu Baru Kecamatan Sorawolio Kota Baubau. Jurnal Pengabdian Kepada Masyarakat Membangun Negeri Vol. 2 No. 1 Juni 2018.

Kaswan. 2012. Manajemen Sumber Daya Manusia untuk Keunggulan Bersaing. Organisasi. Yogyakarta: Graha Ilmu.

Marwansyah. 2010. Manajemen Sumber Daya Manusia, edisi kedua. Bandung: Alfabeta.

Moekijat. 2010. Manajemen Sumber Daya Manusia, cetakan kesembilan. Bandung: Mandar Maju.

Terry, GR. 2008. Human Resource Management. Publihed by McGraw Hill, USA

Veithzal Rivai dan Sagala, Jauvani. 2009. Manajemen Sumber Daya Manusia untuk Perusahaan: dari Teori ke Praktik. Jakarta: Rajawali Pers. 